\title{
FURTHER SASKATCHEWAN RACCOON SIGHTINGS
}

VICTOR C. FRIESEN, P.O. Box 65, Rosthern, Saskatchewan. SOK 3R0

Earlier reports in Blue Jay suggest that the Raccoon has been extending its range northward in Saskatchewan in the last 15 years (it is more commonly found in the valleys of the Qu'Appelle and Souris river systems). Harris reported two sightings near Saskatoon (1969). ${ }^{2}$ Houston and Houston reported two more records for the Saskatoon area (1971 and 1972); sightings at Leslie and Delisle (1972); as well as more northerly records at Mullingar (1968), Northside (1969-70), and Christopher Lake (1969-70, 1972). ${ }^{3}$ Previous records for points farther north are given by Beck for Meadow Lake and by Krivda for Sipanok Channel, near Squaw Rapids (1950). ${ }^{14}$

Filling the gap between sightings at Saskatoon and those at Northside and Christopher Lake, north of Prince Albert, are two observations I made this spring. On 14 May 1983, I came across a freshly killed Raccoon on Highway No. 11 just $9 \mathrm{~km}$ southwest of Rosthern (see illustration). It was probably killed the preceding night in its nocturnal wanderings, for it was not there the evening before when I passed.

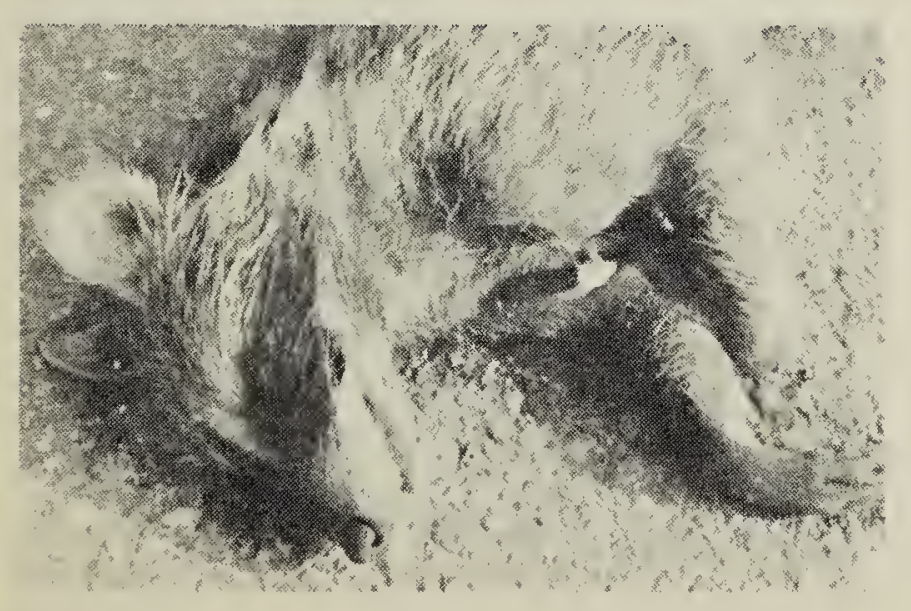

Road-killed Raccoon near

Rosthern.
A week later, on 22 May 1983, I came across another road-killed Raccoon, this time $5 \mathrm{~km}$ north of Petrofka Bridge on Highway No. 12 leading to Blaine Lake.

Raccoons have not previously, to my knowledge, been seen in this area. I discussed my sightings with my uncle, Abe Martens, who farms $5 \mathrm{~km}$ southeast of Prince Albert, and he informed me that in March 1975 he found a Raccoon frozen under a pile of hay bales in his yard. He had contemplated skinning it and selling the fur, but consultation with a local fur buyer had convinced him that doing so would not be worth his while.

The extension of the Raccoon's range during these last years in the areas of the Saskatchewan rivers (my sightings, and others, would be included here) may have been furthered by the presence now of crayfish in these waters. This principal food of the Raccoon was not found in the Rosthern area a few decades ago.

Since several of the sightings mentioned in this report were road kills, careful attention by readers to any similar-sized mammals killed on our highways may give still more evidence of the Raccoon's expanding range in our province.

1 BECK, W. H. 1958. A guide to Saskatatchewan mammals. Regina, Sask. Nat. Hist. Soc. Spec. Pub. 1. 52 pp.

2 HARRIS, W. C. 1971. Some recent Saskatchewan Raccoon records. Blue Jay 29:214.

3 HOUSTON, C. S. and M. I. HOUSTON. 1973. A history of Raccoons in Saskatchewan. Blue Jay 31:103-104.

4 KRIVDA, W. 1982. Northern raccoon records. Blue Jay 40:222. 